\title{
Non-oil Revenue Impact on Economic Growth: Empirical Study of Saudi Arabia's Economy
}

\author{
Dr. Nedra Shili (Corresponding author) \\ College of Business Administration, Jazan University, Jazan, Saudi Arabia \\ E-mail: nshili@jazanu.edu.sa; nedrashili@gmail.com \\ Dr. Kavita Panjwani \\ College of Business Administration, Jazan University, Jazan, Saudi Arabia \\ E-mail: kbanjwani@jazanu.edu.sa
}

Received: August 27, 2020 Accepted: September 18, 2020 Published: September 28, 2020

doi:10.5296/ber.v10i4.17587ＵRL: https://doi.org/10.5296/ber.v10i4.17587

\begin{abstract}
The kingdom of Saudi Arabia saw during the year 2019 an improve in its business environment, as indicated in the World Bank Ease of Doing Business 2020 report in which the Kingdom was the best reformer, gaining 30 places to place itself in $62^{\text {nd }}$ position. $62 \%$ of the three hundred planned reforms in this area have been completed, including a new law on tenders and public procurement, new commercial courts, and a new concurrence law and planned laws on public-private partnerships. The country has recently released the VAT regulation for public consultation through the tax authority (GAZT) website. The VAT introduction presents an important policy in a country where economic system has always relied on oil revenues. The purpose of this study is to show the marked contrast between the impact of non-oil tax revenue (NOTR) and non-oil non-tax revenue (NONTR) on economic growth in Saudi Arabia.

This study applied various essential statistical tools such as descriptive and correlation, paired sample t-test. The results demonstrate that NONTR and NOTR were positive and firmly associated with Nominal domestic product with Co-efficient $(r=.888, p>0.05)$ and $(r=.960, p$ $<0.05)$. The findings outline a significant divergence between the impact of NONTR and NOTR on nominal gross domestic product as shown $\left(\mathrm{t}_{3}=23.310, \mathrm{p}<0.05\right)$ and $\left(\mathrm{t}_{3}=23.099, \mathrm{P}<\right.$ 0.05) based on four years of data from 2016-2020. In this paper, we try to explore the revenue composition of Saudi Arabia and its impact on its economy.
\end{abstract}




\section{MInstitute ${ }_{\text {Mnk }}^{\text {Macrothink }}$}

Keywords: Non-oil non-tax revenue, Tax revenue, Oil revenue, Nominal domestic product, Economic growth, Saudi Arabian economy, Value added tax, General authority for Zakat and $\operatorname{tax}$

\section{Introduction}

States budget has both economic and social influence. It is different from other public bodies and composed mainly of revenues and expenses. States' revenues come from two origins: tax revenue and non-tax revenue. In a context where many countries are facing a decline in their revenue, coupled with increased expenditure, they find their system obliged to meet the resulting budgetary deficiency. Therefore, raising revenue is their main objective, which is a primary function of tax. States design the financial system in order to collect taxes and other compulsory levies. It important to mention that tax revenues serve primarily in financing public expenditures namely: infrastructure, education, health, stable and consistent legal proceedings, expenditures that increase productivity, and promote investment in physical capital as well as in human capital. Going beyond the simple technique of covering public expenditure, taxation is considered a dominant economic policy instrument capable of reaching the economic optimum if it is appropriately designed. The tax itself is an economic phenomenon that, by the fact of its existence, maintains reciprocal influences with the economic environment.

The stability of public budgets is an essential element for sustainable development. Social services, infrastructure, and essential services such as education and health care are vital boosters of development. To ensure public budget stability, funding methods must come to the extent of the government's resources, namely tax revenue. That explains the close link between taxation and development. The economy of KSA relies mainly on its oil industry, which has turned the country's economic history upside down. In the contemporary world, Saudi Arabia is becoming a pioneer economic force in the Middle East and the wealthiest Arab country. The followed strategic reforms carried out by the authorities as well as foreign direct investments and the soundness of the banking and financial sector have made this country the first economy among Gulf corporation council (GCC) and one of the main globally. However, the kingdom's economy remains heavily based on Oil, and the fall in oil prices brought out a slower growth. In the Kingdom of Saudi Arabia, oil represents more than $40 \%$ of GDP, almost $70 \%$ of tax revenues, and approximatively $80 \%$ of exportations. Non-oil activity depends strongly on government expenditures financed by oil revenues (IMF Country Report No. 19/291). 


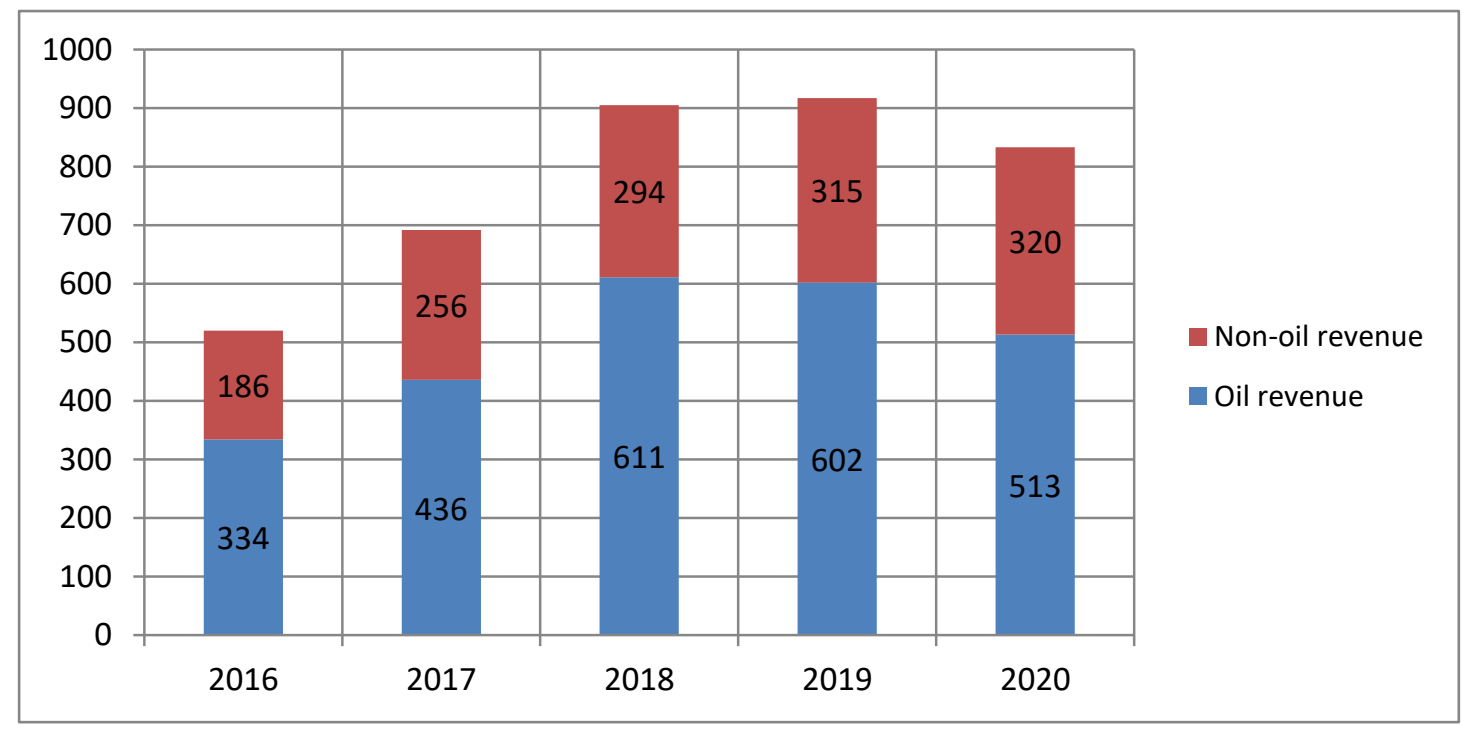

Figure 1. Public Revenue in KSA (SAR billion)

Source: 2020 Budget Statement Mof, IMF

Since late 2018, the Saudi economy recorded a slight budget deficit because of the decline in oil revenues as a result of $\mathrm{OPEC}^{+}$agreement. According to the budget statement of the FY2020, KSA's revenues are expected to decline to SAR 833, and non-oil revenues, expanding swiftly due to greater progress in key projects of 2030 vision program, are expected to improve in the medium term as they grew by $2.5 \%$ through the first half of the year 2019 (US Saudi Business Council). This explains the Saudi endeavors Since FY2016 for launching innovative fiscal, economic, and structural reforms. It is the main objective to achieve sustainable economic growth independent of oil revenues and focusing on growing non-oil incomes.

Acccording to (Narayan et al., 2007) oil prices tend to change over short periods of time. Since the 1980 s oil price witnessed a continuous oscillation that drove its riskiness. Depending its economic system on oil industry is considered a serious problem (Jawadi et al., 2018). Saudi Arabia, learnt the lesson and sought to hedge its economy against oil price shocks. The Saudi orientation of trimming its economy dependency on oil industry was illustarted in several quintile development plans since 1970. The main objective of all these plans is economic diversification in order to expand the sources of national income (Albasssam, 2015).

On June 6, 2016, the 2030 vision program was launched, it confirmed that the economic strategy of KSA focuses mainly on enhancing resource diversification efforts in order to decrease the dependence of public budget on oil revenues. This national development program tends to launch several reforms it mainly focuses on the increase of the private sector role in the economy, the creation of high value-added industries, the introduction of various taxes, the saudisation of labour market, the sale of 5\% of ARAMCO and the 
introduction of various taxes (Faudot, 2019).

In this context, the Saudi cabinet has targeted the increase of non-oil revenues - composed of - taxes on income, profits and capital gains, taxes on goods and services, taxes on international trade and transactions, other taxes, and other non-oil-revenues ${ }^{1}$. Therefore, non-oil-revenues are mainly tax revenues and non-tax non-oil revenues. The Kingdom of Saudi Arabia's budget report published by KPMG in December 2019 mentions that tax revenues in 2020 are expected to reach $62.5 \%$ of non-oil revenues, whereas non-oil non-tax revenues represent $37.5 \%$.

In this paper, we will study the impact of tax revenues and non-oil non-tax revenue on Saudi nominal GDP in order to analyze the importance payoff of efforts put by the Saudi government in diversifying its revenue resources through the application of various essential statistical tools such as descriptive statistics correlation and paired sample t-test.

\section{Conceptual Review}

\subsection{Economic Growth Theory}

Economic growth is generally measured by the gross domestic product (GDP) considered as the main determinant of a nation's output. Many studies have been conducted in order to find out which economic, financial, technological, social, environmental or even technical indicator has more impact on economic growth. Economic growth is commonly expected to enable economic development that is manifested by the improvement of life and living standards. The main strands of economic development approach are liberal approach followed by neoliberalism which ended by the 2008 crisis allowing the emergence of the mixed economic system that combines capitalism and socialism, and introduced by $\mathrm{P}$. Samuelson (Shili, 2016).

The economic growth theory flows from three main doctrines: Neoclassical growth theory (Solow, 1956; Swan, 1956; Cass, 1965; Koopmans, 1965) supporting the approach of short-run economic growth driven by the increase in capital investment, Endogenous growth theory (Romer, 1986 and 1990; Lucas, 1988; Rebelo, 1990) founding that promotion of knowledge and innovation may lead to higher rates of economic growth and the cumulative causation theory (Veblen, 1915; Myrdal, 1957; Kaldor, 1970). Recent studies have been conducted in order to analyze the factors of economic growth. Dar, A. A., \& AmirKhalkhali, S. (2002) looked for an explanation to the difference of economic growth rate in 19 countries members of OCED over the period of 1971 to 1999 using a random coefficient model. They indicated in their findings that small size countries are more advantageous in terms of productivity growth and productivity of capital due to the policies efficiency of governments. They concluded that the nature of country's institutions accompanied with the government activities is as much important as the government size for the performance growth. From another side, Liang, Q. \& Jian-Zhou, T. (2006) used a multivariate vector autoregressive (VAR) tool to examine the effect of financial development on economic growth of China

\footnotetext{
${ }^{1}$ Saudi Arabia's 2020 budget review, US Saudi Business Council. ttps://us-sabc.org/saudi-arabias-2020-budget-review/
} 
during the period 1952-2001. The empirical result of their study showed that financial development has an economic and significant relation with economic growth. Aparicio et al., (2016) studied the contribution of institutions in driving higher economic growth and suggested that entrepreneurship opportunities can boost the economic growth. They used a three-stage least square method with data of 43 countries from 2004-2012. Authors concluded that enhancement of entrepreneurship opportunities through the appropriate institutions may impact the economic growth. Going through various theoretical and empirical studies, we can summarize that governments' performance in its social political and economic sectors should seek the raise of its public revenue in order to achieve economic growth through fulfilling its governmental commitments. For oil revenue dependent economies, governmental revenue is taken for granted, however in recent years it was not the case.

\subsection{Impact of Oil Revenue Volatility on Government Revenue}

In most oil dependent countries, the volatility of oil price has a strong impact on their economic growth. Described as the difference between the expected and real oil price, oil price shocks remain unpredictable (Baumeister \& Kilian, 2016a). Oil markets passed into instability and volatility (World Energy Outlook 2018) which has been accentuated with the CVID-19 lockdown and OPEC $^{+}$negotiations. Alekhina \& Yoshino (2018) released a working paper investigating the correlation between macroeconomic indicators of an oil exporting country and world oil prices. They applied a vector autoregressive (VAR) and found out that oil price fluctuations have a high impact on the economic indicators and monetary policies. Limiting the focus on GCC countries, charfeddine \& Barakat (2020) investigated the short and long term impact of oil price volatility and changes of oil and gas revenues on total real GDP of Qatar. They applied two econometrical tools: the A-B structural vector autoregressive model and the nonlinear autoregressive distributed lag. The authors concluded their study by the detection of negative impact due to oil price shocks that do not last for more than three quarters. In their suggestions they outlined the necessary orientation towards economic diversification in order to achieve the oil independence of government revenues.

\subsection{Economic Diversification}

When it comes to diversifying government revenues, the first resort of decision making authorities has always been the implementation of a robust fiscal system that helps the government revenue to have more fund sources. Several studies have been conducted in this context; Burgess et al., (1993) described in their paper the main sources of government revenue and studied the concept and practice of taxation model in disadvantaged countries. They focused on finding whether taxation policies implemented in developed and less-developed countries should be the same or dissimilarity is required due to differences in objectives, responsibilities ad constraints. The authors emphasized a strong link between taxation and expenditure and concluded that the design of taxation in developing countries is entirely unsimilar to that of developed countries. Elizabeth L. Roos \& Philip D. Adams (2019) in their paper studied the economic effect of launching a 5 percent VAT and a tax on profit using a dynamic CGE (computable general equilibrium) model in the economic system of the Kingdom of Saudi Arabia (KSA). Their analysis demonstrates that markets remain unclear 
causing the decrease of economic efficiency and production due to the adoption of new taxes. According to this study, real GDP, real investment, and capital stock fall in the long-run. The key findings of this paper expose that the eventual harm influencing the economic efficiency and production is due to taxes, and fiscal reforms involving both government expenditure reform and identifying non-oil revenue origins. This helps to design an optimal tax system that meets all future requirements for each of the Gulf Countries States. The creation of additional sources of revenues for governments span other sectors than fiscality, Gilles Mourre \& Adriana Reut (2019) conducted a study to provide an analysis of government revenue components mainly non-tax revenue, referring to comparable national accounts data. The study analyzed the size, composition, and volatility of non-tax revenue in the European Union, and it examines, through panel data analysis, whether macroeconomic and fiscal conditions can determine the detected divergence in non-tax revenue across the Member States. Authors found that the relative volatility of non-tax revenue is around three times higher than that of tax revenue, being an important origin of fiscal risk. Among gulf countries, Saudi Arabia is the greatest oil exporter. The year 2017 presented a recession that reached $-0.7 \%$ of KSA's GDP, due to low oil prices, the Saudi economy returned to positive growth in $2018(+2.4 \%)$. In 2019, growth should be almost zero at $+0.2 \%$ in a context of reduced oil production in application of the $\mathrm{OPEC}^{+}$agreement of December 2018. Economic growth was expected to rebound to $2.2 \%$ in 2020. However, in accordance with COVID-19 lockdown worldwide accompanied with instability of oil prices and political tugging and pulling, economic activity is contracting and economic growth is less than expected.

Ministry of finance (Mof), declared in the quarterly budget performance report (Q1 of FY 2020) that Saudi Arabia's budget deficit stands at 34.107 billion Saudi riyals, with a decline of $24 \%$ in oil revenue and $17 \%$ in non-oil revenue. Though the important share of oil revenues in the Saudi public income, non-oil revenues have a growing role due to the new economic plan. Faudot (2019) analyzed the ability of KSA to overcome the economic challenges and achieve the objectives of 2030 vision plan. The author highlighted in his study the intension of KSA's government to diversify the resources of its revenue. He viewed that Saudi Arabia is still facing a bleak scenario and suggested the kingdom to start more effective reforms such as enhancing tourism or even raise pressure on immigrant labour manifested mainly by the impose of fees on dependents of expatriates workers.

Starting from the evaluation of the Saudi economic reforms plan and the 2030 vision which have the main objective of oil independence, we found it crucial to analyze the effect of non-oil revenue on Saudi economic growth in order to find out the feasibility of applied economic strategies as the national transformation program set out specific commitments for the period up to 2020. In the previous studies we could not find any analysis of the above mentioned investigation. Therefore, we try in this paper to analyze the impact of non-oil revenue on Saudi GDP distributing the non-oil revenue into: tax revenue and non-oil non-tax revenue.

\subsection{Elements of Saudi Arabia's Revenue}

The sharp drop in oil prices between 2014-2016 stokes the need of oil dependent economies 
to remold their economic systems. Oil exporters that witnessed the shock tended to adopt a stronger fiscal position (Grigoli et al., 2019). Historically, economic roars in Saudi Arabia were results of increased oil price (Albassem, 2015). Accordingly, economic reforms implemented in 10 development plans from 1970 to 2019 in KSA encourage the reduction of oil dependency in order to enhance sustainable economic development (Ministry of Economy and Planning, 2014).

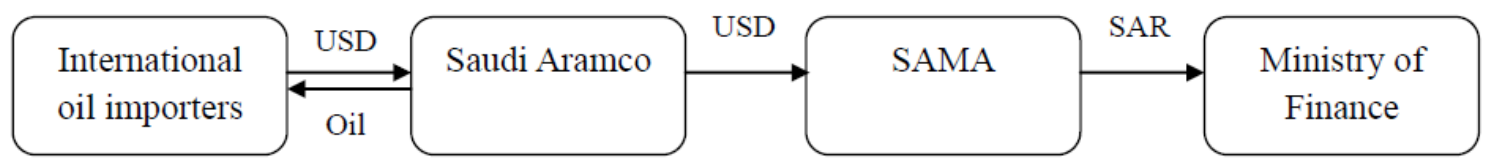

Figure 2. Oil income flow in Saudi Arabia

Source: Adapted from (Faudot 2019), SAMA:Saudi Arabian Monetary Authority.

Figure 2 presents the oil income flow and shows the important process through which the exchange value of oil determined on international markets will impact the Saudi Gross Domestic Product. Recently with the emergence of 2030 vision plan, KSA had resort to the enforcement and solid construction of its fiscal system. The main purpose of implemented fiscal and economic reforms is to speed up the economic reshape and maintain fiscal sustainability through high rate of economic growth and low budget deficit. Since 2016, VAT has been implemented as well as a set of measures such as: expat levies, and energy price reforms. These new measures had a growing impact on government revenue.

According to Mof reports, the Saudi revenue is composed by: oil revenues and non-oil revenues. Abounding studies have treated the Saudi oil-revenue topic, in this study we will put the light on non-oil revenues elements. Non-oil revenues mainly expand to non-oil tax revenues and non-oil non-tax revenues. Saudi taxes are implemented through the fiscal balance program, one of the most prominent programs of 2030 vision, launched in 2016. According to the General Authority of Zakat \& Tax, fiscal system is barely manifested in corporate income tax; value added tax, excise tax and withholding tax.

CIT is defined by GAZT as a direct tax applied on non-Saudi shares in resident capital companies, on residents trading in KSA and non-residents realizing an income from a trade in KSA. Value added tax as an indirect tax that has been applied since $1^{\text {st }}$ January, 2018 in order to diversify the Saudi Arabia revenue, VAT rate is 5\% but starting from $1^{\text {st }}$ June, 2020 it will be $15 \%$ due to the economic downturn caused by Covid-19 lockdown and oil price decrease. Excise tax is an indirect tax with varying rates applied on certain commodities harmful to public health and environment. Withholding tax is a direct tax which has been launched since 2004 and is deducted from the revenues realized from a trade in KSA by non-residents.

The category of other revenues is mainly non-tax non-oil revenues which present a part of plans introduced in 2030 vision and its supporting Vision Realization plan with the objective of developing and diversifying non-oil revenues. It has been defined by the ministry of 
finance as revenues from other public government units and sales performed by other entities.

The elements of Saudi Arabia's revenue in the first quarter of 2020 are shown as follows:

Figure 3. Actual Revenues in Q1 of FY 2020

\begin{tabular}{|l|l|}
\hline Revenues & Q1 2020 \\
\hline Oil Revenues & 128,771 \\
\hline Taxes on Income, Profit and Capital Gains (Of which: Foreign Corporate Income Tax) & 3,569 \\
\hline Taxes on Goods and Services (Of which: Excise Tax and VAT) & 30,604 \\
\hline Taxes on International Trade and Transactions (Customs) & 4,021 \\
\hline Other Taxes (Of which: Zakat) & 2,060 \\
\hline Other Revenues & 23,047 \\
\hline Non-oil Revenues & 63,301 \\
\hline Total & 192,072 \\
\hline
\end{tabular}

(SAR Million)

Source: MOF Q1 budget performance reports FY 2020

The first quarter of 2020 report published by the Saudi ministry of finance, shows a budget deficit of 34.107 billion SAR ( $\$ 9.07$ billion). The recorded revenue during this period was $22 \%$ less than the recorded revenue of the same period during 2019. Saudi Arabia's oil revenue fell $24 \%$ while non-oil revenue fell by $17 \%$. This revenue decrease is occurring despite the implementation of more financial and fiscal restrictions presenting one of the consequences of COVID-19 and the restrictive measures taken around the world in order to preserve the health of Saudi citizens. During this worldwide pandemic, the $\mathrm{OPEC}^{+}$agreement came to its end and the oil prices witnessed various instabilities and historical decrease. The Saudi Minister of Finance, Mohammed Al-Jadaan, stated in a press conference that Saudi Arabia is wealthy and able to keep the deficit under control and overtake the Coronavirus crisis.

Since the emergence of the pandemic Saudi financial and economic sectors took precise steps in order to maintain the stability of its ecosystem. In particular, tax policies witnessed a prompt adjustment. The General Authority of Zakat and Tax (GAZT) introduced tax and legal changes aiming at the stimulation of private sector such as suspension of tax filing, payment, voluntary disclosure and affording digital tools in order to help users to optimize their taxes. All of these measures show the importance of tax income and the strong willingness of getting rid of oil revenue dependency.

\section{Research Question and Methodology}

A wide range of socio-economic reforms introduced through the 2030 vision program has been urged in order to reduce the undesired consequences of the heavy dependence on oil, the volatility of oil price, and high government expenditure on the Saudi economy. 
Saudi leadership launched crucial reforms supporting economic diversification, such as opening the market to Foreing Direct Innvestment (FDI) and small businesses and entrepreneurship, labor market reforms, privatization, introducing the VAT system. This situation pushed the focus of this research on looking forward to the feasibility of the essential reform, which marked more the socio-economic system: tax implementation and its impact on enhancing the Saudi government budget.

Therefore, two key issues will be discussed in this paper which are:

1) What is the impact of tax revenues on NGDP?

2) What is the difference between the impact of NOTR and NONTR on NGDP?

To answer to these questions, we studied the Data has been gathered from budget statement and international monetary fund country report fiscal year 2014-2019 and various other resources. Numerous important statistical tools like as descriptive and correlation, paired sample t-test has been applied in this analysis. To evaluate the co-efficient of correlation variables to be considered such as Nominal Gross domestic product, non-oil tax revenue, non-oil non-tax revenues. The hypotheses agreed under this analysis are significant level of 5\% (0.05). SPSS window 23 was used for the analysis of the result.

\section{Findings and Discussions}

Table 1. Descriptive Statistics of Nominal Gross domestic product, Oil tax revenue, Non-oil tax revenue

\begin{tabular}{|l|l|l|l|}
\hline & NGDP & NOTR & NONTR \\
\hline Sum & 10882.00 & 470.00 & 558.00 \\
\hline Range & 528.00 & 79.00 & 101.00 \\
\hline Mean & 2720.5000 & 117.5000 & 139.5000 \\
\hline Minimum & 2419.00 & 82.00 & 99.00 \\
\hline Maximum & 2947.00 & 161.00 & 200.00 \\
\hline Std. Deviation & 262.65884 & 39.11095 & 47.61302 \\
\hline Variance & 68989.667 & 1529.667 & 2267.000 \\
\hline Skewness & -.321 & .229 & .704 \\
\hline Std. error of skewness & 1.014 & 1.014 & 1.014 \\
\hline Kurtosis & -4.157 & -4.539 & -1.998 \\
\hline Std. error of kurtosis & 2.619 & 2.619 & 2.619 \\
\hline Observation & 4 & 4 & 4 \\
\hline
\end{tabular}

Source: Analysis of data from SPSS output, using window 23

Table 1 represents the descriptive analysis of nominal gross product, NOTR, NONTR, for the study. As shown in Table 1, the sum, range, mean minimum, maximum, and variance, as well as the skewness and Kurtosis of our variable of interest, are evident. NOTR (139.50) scored the highest mean than OTR (117.50). The standard deviation of OTR (39.11095) and NOTR (47.61302), respectively.

Hypothesis: There is no significant difference between the effects of non-oil tax revenue and non-oil non-tax revenue on economic growth in Saudi Arabia. 
Table 2. Paired Samples Correlations

\begin{tabular}{|l|l|l|l|l|}
\hline & & $\mathrm{N}$ & Correlation & Sig. \\
\hline Pair 1 & Nominal Gross product \& Non-oil non-tax revenue & 4 & .888 & .112 \\
\hline Pair 2 & Nominal Gross product \& Non oil tax revenue & 4 & .960 & .040 \\
\hline
\end{tabular}

Source: Analysis of data from SPSS output, using window 23

Analysis of table 2 above, the independent variable Non-oil-tax revenue was strongly positive, perfectly correlation with $\operatorname{NGDP}(r=.960, p<0.05)$. At the same time, non-oil non-tax revenue also depicts that positive correlation, and there was linearity in the result with the dependent variable (NGDP), as shown $(r=.888, p>0.05)$.

\begin{tabular}{|l|l|l|l|l|l|l|l|l|l|}
\hline \multicolumn{9}{|c|}{ Paired Sample Test } \\
\hline & & & & $\begin{array}{l}\text { Confidence Interval } \\
\text { of } \\
\text { the difference at 95\% }\end{array}$ & T & df & $\begin{array}{l}\text { Sig } \\
\text { (2-tailed) }\end{array}$ \\
\hline & & Mean & $\begin{array}{l}\text { Standard. } \\
\text { Deviation }\end{array}$ & $\begin{array}{l}\text { Std.Error } \\
\text { Mean }\end{array}$ & Lower & Upper & & & \\
\hline $\begin{array}{l}\text { Pair } \\
1\end{array}$ & $\begin{array}{l}\text { Nominal Gross } \\
\text { product \& } \\
\text { Non oil non tax } \\
\text { revenue. }\end{array}$ & 2581.000 & 221.460 & 110.725 & 2228.624 & 2933.376 & 23.310 & 3 & .000 \\
\hline $\begin{array}{l}\text { Pair } \\
2\end{array}$ & $\begin{array}{l}\text { Nominal Gross } \\
\text { product \& } \\
\text { Non-oil tax } \\
\text { revenue. }\end{array}$ & 2603.000 & 225.381 & 112.691 & 2244.368 & 2961.632 & 23.099 & 3 & .000 \\
\hline
\end{tabular}

The analysis of above table 3 shows that there is significant difference between the effect of non-oil non-tax, and non-oil tax revenue on nominal gross domestic as shown $\left(t_{3}=23.310\right.$, $p<0.05)$ and $\left(t_{3}=23.099, P<0.05\right)$. Therefore, the Alternative hypothesis is accepted, and the Null hypothesis is rejected. It implies that there is a significant difference among non-oil non-tax revenue, and non-oil tax revenue on NGDP. Non-oil non-tax revenue and non-oil tax revenue have an indicative difference in contribution to economic growth in Saudi Arabia at $5 \%$ level, which comprised of revenue from companies' income tax, capital gain, taxes on services and goods, taxes on international business and other revenues. Results depicted in this study that positive and robust correlations exist between non-oil non-tax revenue and non-oil tax revenue and gross domestic product.

\section{Conclusion and Recommendations}

According to our findings, tax revenues which represented 132 billion SAR of Saudi Arabia's revenue for 2019 have stronger impact on nominal gross domestic product than non-oil non-tax revenue generated from agriculture, non-oil mining, non-oil manufacturing, electricity, gas and water, construction, wholesale and retail trade, transport and communication, ownership of dwelling, finance, insurance and business, community and social services and producers of government services. This result may be the logic outcome 
of the government endeavors in building a robust fiscal system in order to achieve one of the 2030 vision objectives- which is reducing the economic dependency on oil revenues. Taxation remains the first solution when the budget faces shortage and difficulties. Due to Covid-19, Saudi Arabia announced recently an austerity plan in which it will triple its VAT and end monthly payments to its citizens after the fall of the price of oil, which plummets the country's economy. It is important to mention that, taxation is one of any country's fund resources but it remains insufficient and has counter consequences. Increasing tax rates leads logically to tax burdens workers and entrepreneurs, consequently, purchase power parity will decline, inflation will increase therefore, there will be a production drop and then government revenue will decrease. Instead of tax ceiling, it is more advantageous to encourage domestic production to increase the taxation base in order to become a self-reliant and self-sufficient government. It is necessary as well that the kingdom puts more effort in economic diversification plan and support other non-oil sectors such as tourism, agriculture, FDI, entrepreneurship for better economic growth.

\section{References}

Albassam, B. A. (2015). Economic diversification in Saudi Arabia: Myth or reality?. Resources Policy, 44, 112-117. https://doi.org/10.1016/j.resourpol.2015.02.005

Alekhina, V., \& Yoshino, N. (2018). Impact of World Oil Prices on an Energy Exporting Economy Including Monetary Policy. ADBI Working Paper 828.Tokyo: Asian Development Bank Institute.

Ansari, D. (2017). OPEC, Saudi Arabia, and the shale revolution: Insights from equilibrium modelling and oil politics. Energy Policy,Elsevier, 111(C), 166-178.

https://doi.org/10.1016/j.enpol.2017.09.010

Aparicio, S., Urbano, D., \& Audretsch, D. (2016). Institutional factors, opportunity entrepreneurship and economic growth: Panel data evidence. Technological Forecasting and Social Change, Elsevier, 102, 45-61. https://doi.org/10.1016/j.techfore.2015.04.006

Baumeister, C., \& Kilian, L. (2016). Forty Years of Oil price Fluctuations: Why the Price of Oil May Still Surprise US. Journal of Economic Perspectives, 30(1), 139-160.

https://doi.org/10.1257/jep.30.1.139

Burgess, R., \& Stern, N. (1993). Taxation and Development. Journal of Economic Literature, American Economic Association, 31(2), 762-830.

Cass, D. (1965). Optimum Growth in an Aggregative Model of Capital Accumulation. Review of Economic Studies, 32, 233-240. https://doi.org/10.2307/2295827

Charfeddine, L., \& Barkat, K. (2020). Short-and long-run asymmetric effect of oil prices and oil and gas revenues on the real GDP and economic diversification in oil-dependent economy. Energy Economics, Elsevier, 86, 104680. https://doi.org/10.1016/j.eneco.2020.104680

Chen, B. L. (1997). Economic growth : Robert J. Barro and Xavier Sala-i-Martin. Elsevier, Journal of Economic Dynamics and Control, 21(4-5), 895-898. 
https://doi.org/10.1016/S0165-1889(97)00007-9

Dar, A. A., \& AmirKhalkhali, S. (2002). Government size, factor accumulation, and economic growth: evidence from OECD countries. Journal of policy modeling, 24(7-8), 679-692. https://doi.org/10.1016/S0161-8938(02)00163-1

Elizabeth, L. R., \& Philip, D. A. (2019). Fiscal Reform - Aid or Hindrance: A Computable General Equilibrium (CGE) Analysis for Saudi Arabia. Centre of Policy Studies/IMPACT Centre Working Papers g-301, Victoria University, Centre of Policy Studies/IMPACT Centre.

Faudot, A. (2019). Saudi Arabia and the rentier regime trap: A critical assessment of the plan Vision 2030. Resources Policy, Elsevier, 62, 94-101.

https://doi.org/10.1016/j.resourpol.2019.03.009

Gilles, M., \& Adriana, R. (2019). Non-tax revenue in the European Union: A source of fiscal risk?. International Institute of Public Finance, 26(1), 198-223.

https://doi.org/10.1007/s10797-018-9498-z

Grigoli, F., Herman, A., \& Swiston, A. (2019). A crude shock: explaining the short-run impact of the 2014-16 oil price decline across exporters. Energy Econ, 78, 481-493. https://doi.org/10.1016/j.eneco.2018.11.025

Hamdi, H., \& Sbia, R. (2013). Dynamic relationships between oil revenues, government spending and economic growth in an oil-dependent economy. Economic Modelling, 35, 118-125. https://doi.org/10.1016/j.econmod.2013.06.043

IEA. (2018.) World Energy Outlook 2018. IEA, Paris. [Online] Available:

https://www.iea.org/reports/world-energy-outlook-2018.

International Monetary Fund, Non-oil Revenue for General Government for Saudi Arabia retrieved from FRED, Federal Reserve Bank of St. Louis.

Ivanyna, M., \& Von Haldenwang, C. (2012). A comparative view on the tax performance of developing countries: Regional patterns, non-tax revenue and governance. Economics E-Journal, 6, 1-44. https://doi.org/10.5018/economics-ejournal.ja.2012-32

Jawadi, F., Jawadi, N., \& Cheffou, A, I., (2018). Toward a new deal for Saudi Arabia: oil or Islamic stock market investment?. Applied Economics, 50(59), 6355-6363.

https://doi.org/10.1080/00036846.2018.1486018

Kaldor, N. (1970). The Case for Regional Policies. Scottish Journal of Political Economy, 17, 337-348. https://doi.org/10.1111/j.1467-9485.1970.tb00712.x

Koopmans, T. C. (1965). On the Concept of Optimal Economic Growth. Pontificae Academiae Scientiarum Scripta Varia, 28, 225-300.

Liang, Q., \& Jian-Zhou, T. (2006). Financial development and economic growth: Evidence from China. China economic review, 17(4), 395-411.

https://doi.org/10.1016/j.chieco.2005.09.003 
Lucas, R. (1988). On the Mechanics of Economic Development. Journal of Monetary Economics, 22, 3-42. https://doi.org/10.1016/0304-3932(88)90168-7

Morrison, K. M. (2009). Oil, Nontax Revenue, and the Redistributional Foundations of Regime Stability. International Organization, Cambridge University Press, 63(1), 107-138. https://doi.org/10.1017/S0020818309090043

Myrdal, G. (1957). Economic Theory and Underdeveloped Regions. London: Hutchinson.

Narayan, P. K., \& Narayan, S. (2007). Modelling oil price volatility. Energy policy, 35(12), 6549-6553. https://doi.org/10.1016/j.enpol.2007.07.020

Petrakos, G., Dimitris, K., \& Ageliki, A. (2007). A generalized model of regional economic growth in the European Union. No. DYNREG12.

Popoola, A. A., Jimoh, I. A., \& Adeyemi, O. A. (n.d.). Tax Revenue and Nigerian Economic Growth. Auditing and Finance Research, European Journal of Accounting, 5(11).

Rebelo, S. (1990). Long Run Policy Analysis and Long Run Growth. NBER Working Paper, 3325. https://doi.org/10.3386/w3325

Romer, P. M. (1986). Increasing Returns and Long Run Growth. Journal of Political Economy, 94(2), 1002-1037. https://doi.org/10.1086/261420

Romer, P. M. (1990). Endogenous Technological Change. Journal of Political Economy, 98(5), 71-102. https://doi.org/10.1086/261725

SAMA. (2018). 54th Annual Report. Saudi Arabia Monetary Agency, Riyadh.

Shili, N. (2016). Economic Emergence an Unachieved Concept to Study Economic Development Theoretical and Empirical Investigation. Journal of Economics, 4(2), 159-169.

Solow, R. M. (1956). A Contribution to the Theory of Economic Growth. Quarterly Journal of Economics, 70, 65-94. https://doi.org/10.2307/1884513

Swan, T. W. (1956). Economic Growth and Capital Accumulation. Economic Record, 32, 334-361. https://doi.org/10.1111/j.1475-4932.1956.tb00434.x

US Saudi Business Council. [Online] Available:

https://us-sabc.org/saudi-arabias-2020-budget-review/

Veblen, T. (1915). Imperial Germany and the Industrial Revolution. London: Macmillan. https://doi.org/10.2307/29738138

\section{Copyrights}

Copyright for this article is retained by the author(s), with first publication rights granted to the journal.

This is an open-access article distributed under the terms and conditions of the Creative Commons Attribution license (http://creativecommons.org/licenses/by/4.0/) 